\title{
Jakuba Sobieskiego opisanie wyprawy na Moskwę (na podstawie Diariusza ekspedycyjej moskieweskiej dwuletniej królewica Wtadystawa Anno Domini 1617)
}

Przedmiot omówienia stanowią dwa diariuszowo-pamiętnikarskie teksty Jakuba Sobieskiego, poświęcone wyprawie moskiewskiej (1617-1618) królewicza Władysława. Zostały one spisane - warto w tym miejscu przypomnieć - gdy Sobieski, wybitny barokowy orator ${ }^{\mathrm{I}} \mathrm{i}$ diarysta, był dopiero u progu swej drogi twórczej w zakresie dzienników wojennych i peregrynackich $^{2}$. Kilka lat wcześniej powstała Peregrynacja po Europie [1607-1613]3, natomiast od lat 20. początku XVII stulecia daje się zauważyć znaczący przyrost narracji wspomnieniowych tworzonych przez ojca Jana III. Wśród znanych obecnie przekazów trzeba wymienić następujące: Dziennik wyprawy chocimskiej r. 16214, Droga do Baden [1638]5, Commentariorum Chotinensis belli libri tres ${ }^{6}$, Diariusz ekspedycyji ukrainnej z Kozakami zaporoskimi w $r .16257$, a ponadto kilka rękopiśmiennych relacji

${ }^{\text {I }}$ Wykaz mów magnata - zob. M. Barłowska, Jakub Sobieski pamięci wielkiego kawalera Barttomieja Nowodworskiego, Szczecin 2006, s. XCIV-CXIV. Na talent oratorski Sobieskiego zwraca uwagę monografistka jego biografii - zob. Z. Trawicka, Jakub Sobieski (1591-1646). Studium z dziejów warstwy magnackiej w Polsce doby Wazóre, Kraków 2007.

${ }_{2}$ Zob. typologię egodokumentów epoki staropolskiej w: A. Sajkowski, Nad staropolskimi pamiętnikami, Poznań 1964.

3 J. Sobieski, Peregrynacja po Europie [1607-1613], Droga do Baden [1638], oprac. J. Długosz, Wrocław-Warszawa-Kraków 1991 (wcześniejsze wydanie: Dwie podróże Jakuba Sobieskiego, odbytepo krajach europejskich w latach 1607-1613 i 1638, wyd. E. Raczyński, Poznań 1833).

${ }_{4}^{4}$ J. Sobieski, Dziennik wyprawy chocimskiejr. 1621, w: Pamiętnikio wyprawie chocimskiej r. 1621, wyd. Ż. Pauli, Kraków 1653.

5 Zob. przyp. 3.

${ }^{6}$ J. Sobieski, Commentariorum Chotinensis belli libri tres, Gdańsk 1646 (w przekładzie: Pamiętnik wojny chocimskiej ksiag troje, przeł. z łac., życiorysem autora i objaśnieniami uzup. W. Syrokomla, Petersburg 1854).

7 J. Sobieski [?], Diariusz ekspedycyji ukrainnej z Kozakami zaporoskimi w r. 1625, w: J.U. Niemcewicz, Zbiór pamiętników o dawnej Polsce, Lwów 1833, t. 6, s. 264-421. 
o bieżących wydarzeniach drugiej, trzeciej i czwartej dekady wieku XVII ${ }^{8}$.

Moskiewskie relacje wspomnieniowe Jakuba Sobieskiego zachowały się do naszych czasów w kilku kopiach, z których najważniejsze znajdują się w zbiorach Biblioteki Czartoryskich w Krakowie. Podstawę rekonstrukcji pochodu następcy tronu do Moskwy stanowi głównie rękopiśmienny przekaz zatytułowany Diariuszekspedycyjej moskiewskiej dwuletniej królewica Wtadystawa Anno Domini 1617 pisany przez JMP Jakuba Sobieskiego komisarza tejże ekspedycyjej ${ }^{9}$. Wydarzenia opisane w dzienniku obejmują okres od 5 kwietnia 1617 r. do 28 grudnia 1618 r. W ostatnim akapicie diarysta nadmienił jeszcze, iż wespół z innymi dygnitarzami pośpieszył na sejm do Warszawy (obrady trwały do 5 marca).

Autor zastosował $\mathrm{w}$ dziele kryterium chronologicznego uporządkowania materiału ${ }^{\mathrm{Io}}$, zwracając uwagę przede wszystkim na jego funkcję poznawczą. Zakończenie tekstu, w którym Sobieski przywołuje fragment roczników Tacyta, wskazuje na rolę perswazyjną diariusza. Miał on służyć jako wytłumaczenie przed Rzeczpospolitą (król, sejm, senat, szlachta), iż komisarze słusznie zawarli traktat dywiliński, mając na względzie bezpieczeństwo kraju (w sytuacji zagrożenia turecko-tatarskiego) oraz pustki w skarbie koronnym i litewskim ${ }^{\mathrm{II}}$.

W relacji czytamy:

Ja z ks[iędzem] biskupem i z panem kanclerzem pospieszyliśmy się na sejm do Warszawy, wdzięcznie od wszytkich przyjęci, tylko król Je[g]

${ }^{8}$ J. Sobieski, Traktatów komisyi pruskiej relacyja, rkps Bibl. Czart., sygn. 3911 IV, s. 81-112; idem, Diariusz interregnum po Zygmuncie III A[nno] D[omini] 1632, rkps Bibl. Czart., sygn. 3911 IV, s. 114-138; idem, Pacta induciarum sexenannalium per diarium opisane A[nno] D [omini] 1629, rkps AGAD, APP 31, t. 2, s. 681-833; idem, Acta interregni po śmierci K.J.M. Zygmunta III $i$ diariusz sejmu koronacyjej Wtadystawa IV w domu J[ego] M[ości] P[ana] J[akuba] Sobieskiego pisane A[nno] D[omini] 1632, rkps AGAD, APP 303, k. 1-1272 (zob. też rkps Bibl. Czart., sygn. 363 i 366 ).

9 Tak brzmi pełny tytuł w rękopisie ze zbiorów Bibl. Czart., sygn. 2763 IV (brulion tamże, sygn. 3911 IV). W dalszej części cytuję dziennik według ostatniego wydania po porównaniu z wersją rękopiśmienną - J. Sobieski, Diariusz ekspedycyjej moskiewskiej dwuletniej królewicza Wtadystawa 1617-1618, oprac. J. Byliński, W. Kaczorowski, Opole 2010, s. 9-95. Rękopiśmienna XIX-wieczna kopia diariusza znajduje się w Bibliotece PAN w Kórniku, sygn. 328 (poza kilkudziesięcioma odmianami w zapisie nazw miejscowych oraz nazwisk oba przekazy są identyczne). Zob. też odpis w Bibl. Czart., sygn. 110 IV, dok. nr 188.

то Wedle klasyfikacji diariuszów zaproponowanej przez A. Sajkowskiego Diariusz ekspedycyjej moskiewskiej realizuje model diariusza regularnego - zob. A. Sajkowski, op.cit., s. 47-50.

II Szczegółowe wyliczenia zobowiązań skarbu państwa wobec żołnierzy podaje Anna Filipczak-Kocur w książce Skarbowość Rzeczypospolitej 1587-1648. Projekty - ustawy - realizacja, Warszawa 2006, s. 132-135. 
o M[iłość] sam tę pracę naszą iniquo animo przyjął z podziwieniem wszytkich i gdyśmy in facie Reip[ublicae] relacyją czynili tych traktatów i pacta oddali, miasto podziękowania ks[iądz] Lipski, biskup łucki, który na ten czas był podkanclirzym, gorętsze aniż była króla Je[g]o M[iłoś]ci wola, w responsie swym od króla Je[g]o M[iłoś]ci inwektywy na nas czynił. Mógłby się był łacno konfundować od nas pokazaniem listów króla Je[g]o M[iłoś]ci, które z jego kancelaryjej wychodzili, gdzie nam quibus vis conditionibus pokój zawierać kazano, ale że był to sejm inszemi różnemi hałasami uwikłany, woleliśmy wszytko to modestyją naszą a prawdą samą samym sobie nagrodzić. Jakoż czas sam ukazał, który wszytkich rzeczy bywa najpewniejszym mistrzem, że barzo się dobrze in rem Reipub[licae] stało i z samego króla Je[g]o M[iłoś]ci potym ukontentowaniem, żeśmy byli tak pacta z Moskwą zawarli. Skąd niech każdy civis ma to sobie za doświadczoną naukę, że służąc ojczyźnie dobrą intencyją, całą wiarą i cnotą, nigdy reputacyjej swej dobrej nie straci i jeśli ex livore malevolorum weźmie jaki niesmak, przecie czas sam i posteritas vigente invidia suum cuique decus rependet ${ }^{\mathrm{I} 2}$.

Podsumowanie diariusza uświadamia, iż intencją nadawcy była obrona komisarzy wyznaczonych przez sejm do pomocy i kontroli poczynań królewicza oraz głównodowodzącego armią Jana Karola Chodkiewicza ${ }^{\mathrm{I}}$. Posiadając instrukcję, by dążyć do zawarcia traktatu (o ile nie uda się objąć moskiewskiego tronu), Sobieski kreuje swe poczynania jako wypełnienie woli sejmu oraz monarchy ${ }^{\mathrm{I} 4}$. Zwrot „jakoż czas sam ukazał” zdaniem autora z jednej strony wskazuje na słuszność podjętej decyzji, z drugiej natomiast potwierdza, iż zakończenie diariusza wojewodzic lubelski dopisywał nieco później, najpewniej po obradach sejmu 1619 r., gdzie skrytykowano pakta moskiewskie ${ }^{\mathrm{I} 5}$. Wtedy już wiadomym było, że zarówno król ${ }^{\mathrm{I}}{ }$, jak i senatorowie, a po części również szlachta, nie pochwalają zawartego na czternaście i pół roku rozejmu (do 3 lipca 1633 r. ${ }^{\text {I7 }}$. Powołanie się na autorytet

I2 J. Sobieski, Diariusz ekspedycyjej..., s. 94-95.

I3 Komisarzy było ośmiu: Andrzej Lipski (biskup łucki), Andrzej Męciński (poseł sandomierski), Piotr Opaliński (starosta śremski), Konstanty Plichta (kasztelan sochaczewski), Lew Sapieha (kanclerz litewski), Jakub Sobieski (wojewodzic lubelski), Baltazar Strawiński (starosta mozyrski), Stanisław Żórawiński (kasztelan bełski).

${ }^{{ }_{4}}$ Z. Trawicka, op.cit., s. 88.

I5 Por.: J. Rzońca, Ostatni sejm przed Cecora (w 1619 r.), „Pamiętnik Biblioteki Kórnickiej” 1983, z. 20, s. 42; Z. Trawicka, op.cit., s. 93-94.

r6 Zob. M. Lepecki, Pan Jakobus Sobieski, Warszawa 1985, s. 91 i n.

I7 Jarema Maciszewski wyraził opinię, że w świetle materiałów „przeważały nastroje przeciwne wojnie z Moskwą”. Sąd ten nie idzie w parze z przekonaniami Sobieskiego, który musiał odczuwać falę krytyki, zwłaszcza ze strony króla i czę- 
Tacyta w łacińskiej maksymie, iż to potomność osądzi słuszność decyzji komisarzy, stanowi rodzaj argumentu zbijającego racje zawistnych oponentów.

W kontekście zakończenia diariusza warto przywołać również fragment pamiętnika, w którym Sobieski zrekonstruował dzieje moskiewskiej smuty. Utwór posiada niejednorodną strukturę narracji, gdyż poza partiami diariuszowymi zawarto w nim fragmenty relacji pamiętnikarskiej oraz kronikarskiej, a ponadto autor wprowadził doń oryginalną korespondencję. Sobieski, rekapitulujący wypadki moskiewskie od śmierci cara Iwana IV Groźnego (1584), doprowadził swą relację do schyłku roku 1618, a więc polsko-moskiewskich ustaleń dywilińskich. W zakończeniu dziełka notował:

Z tego krótkiego tragedii moskiewskiej opisania siła rzeczy do wiadomości i uważenia godnych, do pamięci wielce potrzebnych znaleźć i przeczytać się mogą. Naprzód sprawiedliwa, cudowna prawie pomsta Boska nad Borysem Godunem, carem moskiewskim, za okrutne przezeń zamordowanie praeter dominandi cupiditatem Dmitra Uhleckiego, syna kniazia moskiewskiego Wasila, tyrana, prawdziwego państwa moskiewskiego dziedzica. Po wtóre, kaźń Pańska generalna na wszytkę ziemię moskiewską, która post decessum legitimorum dominorum zaraz się wszczęła, długi czas trwała dividia Moscorum [...] się równające ekshaust i siły ich attrivit, że Polonos et Lithuanos, których olim Moscovia triumphavit, victorem vidit. Po trzecie, strącenie i zniżenie z stolice moskiewskiej jednych, którzy się w cudzą osobę wdzierając i wcielając (jako dwóch Dmitrów impostorów), drugiego zaś, który per fraudem et tyrannidem (jako Szujskiego okupując, regiment monarchii moskiewskiej na sobie trzymali, a strącenie Szujskiego z wielką hańbą narodu moskiewskiego, naszą zaś nieśmiertelną sławą). Czwarta rzecz, abo raczej jasny dowód, że KJM PNM do wojny moskiewskiej nie dał żadnej ansy, a pogotowiu panowie senatorowie nie byli tej wojny $[. .$.$] pryncypałami$ i autorami, ale perfidia i złość Szujskiego, na stolicy moskiewskiej hardzie rozkazującego, roznieciła tę wojnę, którą JKM, jako czuły ludu sobie od Boga powierzonego pasterz, w czas obviando, szedł $\mathrm{z}$ wojskiem swym na Ukrainę tuere fines Regni, a za podaniem się okazyjej awulsa swe recuperare, jakoż pobłogosławić Pan Bóg raczeł, że najprzedniejsze oblatum Smoleńska regimini suo subiecit. Piąta rzecz, jako Moskwa, dziedziczny i główny narodu naszego nieprzyjaciel,

ści magnatów (zob. J. Maciszewski, Polska a Moskwa 1603-1618. Opinie i stanowiska szlachty polskiej, Warszawa 1968, s. 307-308). O zaufaniu izby poselskiej do pracy komisarzy pisała też Z. Trawicka $\mathrm{w}$ artykule Pozasejmowa działalność polityczna Jakuba Sobieskiego („Sobótka” 1980, nr 2, s. 173). 
sami ultro non rogati nec requisiti królewica JM Władysława za pana sobie obrali, przysięgę mu wykonali, przez posły swe jedne i drugie KJM suplikowali, aby im królewica JMci na państwo moskiewskie dać raczeł, pod tytułem królewica JMci złotą i srebrną monetę bili i państwo moskiew[skie] długi czas rządzili. [...] Szósta a ostatnia rzecz, albo raczej justyfikacyja Ichmć panów komisarzów przy królewicu JMci w Moskwie będących, że ten pokój, który przez Ichmć z Moskwą na lat 14, miesięcy 6 jest zawarty, stanąć necessario musiał. Gdyż ani potęgi i mocy, którą by Moskwę do poddaństwa królewicowi JMci przywieść i aby go za pana przyjęli, przymusić, nie było, nawet nadzieje żadnej o posiłkach nie czyniono, owszem, szczupłości pieniędzy w skarbiech w liściech coraz przekładano. Moskwa zaś, z kilku miejsc gromadzeni, następowali do stolice wojskami. Do tego też żadnej skłonności żadnej w Moskwie ku królewicowi JMci wyciągnąć nie mogli Ichmć panowie komisarze. [...] Nadto zatem pokój z Moskwą zawarty jest pokój utcziwy, pokój pożyteczny, pokój wielu potrzebny. Utcziwy, bo zamki, które waleczny pan św[iętej] pamięci król Stefan ex pactis wrócił niegdy moskiewskiemu, jako Newel i insze, teraz zaś królewicowi JMci tych zamków Moskwa ustąpić musiała. Pożyteczny jest, gdyż całych piętnaście zamków albo raczej powiatów fundit fertilissimi, na kilkadziesiąt mil wzdłuż i wszerz do państw JKM przybyło, rozszerzyło się longe lateque granice koronne i litewskie, i co przedtem chytry nieprzyjaciel Koronie i WKsLit beł wydarł i długo z tego się cieszył łupu, to za szczęściem JKM, za odwaga królewica JMci Władysława, za życzliwą i odważną Ichmć panów komisarzów posługą przez te inducyje znowu się rekuperowało i odzyskało. Potrzebny na koniec jest ten pokój, bo gdyby wojna z Moskwą dotąd trwała, pewnie by siła ludzi i potęgi na tę tam obrócić się musiało stronę i tak by vires nostrae przeciw potężnemu Otomańczykowi dostateczne były. Na koniec temi inducyjami albo zawarciem pokoju intencyi Rzeczypospolitej dosyć się stało, bo na dwu sejmach takową instrukcyją Ichmć panowie komisarze od Rzeczypospolitej wzięli, aby w długą wojnę Rzeczypospolitej nie zaciągali, ciężaru względem zapłaty rycerstwu nie przyczynili, lecz w tem roku (w którem inducyje stanęli) koniecznie aby tę wojnę traktatami kończyli. I w tem wiarę Ichmć panów komisarzów przysięgą obwarowali i onerowali. Do tejże sejmowej Rzeczypospolitej intencyi JKM częstym rozkazaniem przez listy swe Ichmć panom komisarzom stymulować raczeł. Qui ergo favit voluntatem domini et Reipublicae, in nullam iustam incurrit reprehensionem, quin immo summa meretur laudem, którą iż invidia niezbędna Ichmć panom komisarzom wydarła i wzięła, do obmowiska tak znacznej posługi Ichmci pobudziła ludzi, atoli Ichmć, ipso bono contenti opere, od samego Boga nagrody czekają. A na ten czas samą wdzięcznością i dziękczynieniem braci swej Moskwie po- 
granicznej, którzy od ustawicznego niebezpieczeństwa i ostatniej prawie zguby tymi inducyjami wyzwolonemi się być ingenue fatentur kontentując, na rozsądek teraźniejszego i przyszłych wieków ludzi puszczają, jeśli za tę znamienitą swoję posługę taką mieli odnieść wdzięczność i podziękowanie ${ }^{18}$.

Porównanie zakończenia pamiętnika z cytowanym wcześniej zwieńczeniem diariusza prowadzi do kilku spostrzeżeń. Podobnie jak w dzienniku, Sobieski również w memuarze za nadrzędny cel uznał wythumaczenie komisarzy przed adwersarzami, którzy zarzucali delegacji niezgodność podjętych działań z interesem tronu i Rzeczypospolitej. W pamiętniku stara się przekonać czytelników, iż czasy moskiewskiej smuty były realizacją Bożych zamierzeń, w myśl których Polacy mogli przez wiele lat triumfować nad „chytrym nieprzyjacielem”. Polska obecność na moskiewskiej ziemi stanowi wypełnienie Boskiej pomsty za łamanie przysięgi wierności królewiczowi Władysławowi. Sakralizacji sensu wypraw moskiewskich towarzyszy argumentacja świecka, którą posługuje się doskonały retor-pamiętnikarz. Otóż, jego zdaniem, nie było warunków dla wynegocjowania lepszych ustaleń traktatowych: Moskale nie byli zainteresowani panowaniem królewicza, brakowało posiłków wojskowych i pieniędzy na opłacenie żołnierzy, siły wroga skupiały się wokół Moskwy. Sobieski przypomniał również, iż komisarze realizowali ustalenia poprzednich sejmów i wolę królewską, wyrażaną w korespondencji. Na mocy traktatu uzyskano szeroki pas ziem na wschodzie z kilkoma twierdzami; pokój miał umożliwić skupienie się na konflikcie z Portą Otomańską. Ujawniona po zawarciu rozejmu krytyka świadczy, według pamiętnikarza, o zawiści „obmówców”. Dla Sobieskiego istotna jest, poza Bożą nagrodą, wdzięczność mieszkańców pogranicza polsko-moskiewskiego, którzy dotąd trapili się o swój dobytek. Analogicznie, jak w diariuszu, autor liczy na pozytywną weryfikację decyzji komisarzy przez potomność, która wyrazi wdzięczność za ich posługę.

Zastanawiające musi się wydać wzmocnienie argumentacji zawartej w finalnej części pamiętnika w stosunku do diariusza. Niewątpliwie z jednej strony Sobieski bronił delegacji przed krytyką sejmową roku $1619^{\text {I9 }}$ - z drugiej jednak uniwersalizo-

I8 Tak zwany Pamiętnik Jakuba Sobieskiego. Dymitriada i wyprawa królewicza Wtadystawa do Moskwy w latach 1617-1618, w: J. Sobieski, Diariusz ekspedycy$j e j . . .$, s. 165-167 (tekst zawarto w aneksie do edycji). Cytuję według tej edycji po porównaniu z rkpsem Bibl. Czart., sygn. 2726 IV.

I9 Trzeba tu nadmienić, iż późniejszy rozwój wypadków (narastający konflikt polsko-turecki) zdecydował o pozytywniejszej waloryzacji podpisania traktatu. 
wał w narracji pamiętnikarskiej minione już wydarzenia, widząc w nich zarówno ładunek dydaktyczny („Z tego krótkiego tragedii moskiewskiej opisania siła rzeczy do wiadomości i uważenia godnych, do pamięci wielce potrzebnych znaleźć i przeczytać się mogą”), jak i możliwość pozytywnej autokreacji. Na uwagę zasługuje też budowanie historiozofii narodów polskiego i litewskiego, które miały odegrać szczególną rolę w Bożym planie poskromienia tyraństwa moskiewskiego. Artykułowanie tezy o wypełnianiu przez rodaków zamysłów Opatrzności zostanie zresztą rozwinięte w narracjach wspomnieniowych poświęconych kampanii chocimskiej roku 1621.

Problem wzajemnego stosunku diariusza i pamiętnika w zakresie deskrypcji wypadków moskiewskich można rozpatrywać na kilku płaszczyznach. Warto może zaczać od zadomowionej w badaniach opinii o spisywaniu przez Sobieskiego dwóch diariuszów w trakcie kampanii ${ }^{20}$. Asumpt do tego twierdzenia dał, jak wiadomo, Jerzy Ossoliński. W pamiętniku wspominał on o intrygach w polskim obozie, których efektem było wykradzenie diariusza Sobieskiemu i dostarczenie go Zygmuntowi III Wazie.

Zaczęły się tu znowu przeklęte plotki z wojewodzicem lubelskim, którego wyrostka przekupiono, że diariusz, który panu przepisował, królewicowi wydał. Tę robótkę robieł królewic przez sekretarza hetmańskiego, niejakiego Radwana z Wilna, miejskiego synka, który korumpowany i swego własnego pana sekreta wydawał, listy kradł,

Jak zanotował Zbigniew Ossoliński: „Zaczem, gdy przyszło do sejmu przecie more solito, by w największym ogniu Ojczyznej, zwykłymi oracyjami i niedbałymi radami czas sejmowi naznaczony strawili, aż gdy ostatni dzień przychodził, dopiero w wielkiej konfuzyjej, wrzaskach mało nie całą noc siedząc, niecną konkluzyją sejmowi swemu uczynili, dlatego zaniechawszy wszytkich domowych potrzeb i poprawy, obronę tylko Ojczyźnie, i to lada jako, lepić musieli, z skończenia wojny moskiewskiej bardzo się kontentując, i słusznie. Dał był abowiem Pan Bóg na ten czas to szczęście, gdy nawiększe na nas od pogan niebezpieczeństwa następowały tak, że raczej o obronie samych siebie aniż o wojowaniu kogo inszego myślić się musiało, że tak uczciwie, a zgoła z wielką sławą, difficientibus nostris viribus, skończyła się była na ten czas ona wojna nasza moskiewska, choć się co innego królowi JM zdało, który raczej swoję wszytkę w niej zabawiał, nie oglądając się na żadne niebezpieczeństwa nasze ani na tak srogie koszty, w któreśmy się byli nieostrożnie z pochlebnych niektórych rad wdali” (Z. Ossoliński, Pamiętnik, oprac. i wstęp J. Długosz, Warszawa 1983, s. 113-114). Niejednoznaczną opinię w tym zakresie wyraził syn Zbigniewa, Jerzy Ossoliński, który wspomniał o krytyce królewicza, ale równocześnie powszechnym wychwaleniu (zob. J. Ossoliński, Pamiętnik, oprac. i wstęp W. Czapliński, Warszawa 1976, s. 86).

${ }_{20}$ Por.: J. Seredyka, Jedna czy dwie relacje Jakuba Sobieskiego z wyprawy na Moskwę w latach 1617-1618?, „Sprawozdania Opolskiego Towarzystwa Przyjaciół Nauk" 1988, nr 21, s. 61-64; A.A. Majewski, Moskwa 1617-1618, Warszawa 2006, s. 141. 
mowy podsłuchiwał i nieboraka Sobieskiego w taką przyprowadzieł molestyją. Posłał też z tego obozu królewic księdza Szołdrskiego do króla, wrzkomo w inszych sprawach, re vera na hetmana skarżyć, że nic nie robi i jemu sławy i szczęścia zazdrości, a na mię pogotowiu jako autorem wszystkiego złego, prosząc, aby mię rewokowano i skarano; na ostatek na wojewodzica lubelskiego, którego diariusz posyłał królowi. Ale i z tego poselstwa niewiele miał pociechy, bo i na mię odpowiedział król (com zaś potem od samego króla, gdym już w jego pokoju służył, słyszał), że to Kazanowskich złość i zazdrość, i o on diariusz wielce go gromieł, że tak nieprzystojnie cudzych sekretów dostawał, tego dokładając, że „gdybym ja chciał po cudzych szkatułach szukać, co kto o mnie pisze, i królestwo, i zdrowie bym stracił”, na ostatek on diariusz, nie czytawszy go, przy księdzu Szołdrskim wrzucieł w ogien ${ }^{2 x}$.

Pamiętnikarz stwierdził, iż na polecenie królewicza wykradziono wojewodzicowi lubelskiemu przepisywany diariusz, który następnie ksiądz Andrzej Szołdrski zawiózł do króla. Monarcha jednak zdecydował o natychmiastowym spaleniu manuskryptu. Informacja Ossolińskiego została uwiarygodniona przez Jana Seredykę: dowodził on, iż spalono nie diariusz, lecz pamiętnik ${ }^{22}$, w którym brak dokładniejszej deskrypcji wydarzeń sprzed września 1618 r. ${ }^{23}$. Owa luka świadczy, zdaniem uczonego, o zniszczeniu właśnie drugiego przekazu, a nie zachowanego w kilku kopiach diariusza. Taka eksplikacja siłą rzeczy musi budzić zastrzeżenia. Niezależnie bowiem od „legendy” ${ }^{24}$ spalonego diariusza trzeba zauważyć, iż Ossoliński wspomniał o wyrostku przepisującym tekst. Zatem nawet jeśli przekazał jedną kopię stronnikom Władysława, to i tak - by nie ulec dekonspiracji - musiał pozostawić jakiś odpis relacji dla Sobieskiego. Dalsza wątpliwość wiąże się z brakującym fragmentem narracji o wydarzeniach z roku 1617 i większej części następnego. Dokładniejsza lektura zachowanego pamiętnika prowadzi do wniosku, że o żadnej luce nie może być mowy, gdyż mamy do czynienia z celowym zabiegiem syntetyzowania wydarzeń czasów smuty, począwszy od śmierci Borysa Godunowa. Sobieski, opierając się na szczegółowym diariuszu, który pisał w trakcie kampanii, dokonał jego modyfikacji, two-

${ }^{21}$ J. Ossoliński, Pamiętnik, s. 80-81.

${ }^{22}$ Zob. rkps Bibl. Czart., sygn. 2726 IV, s. 11-108.

23 J. Seredyka, op.cit.

${ }_{24}$ O tworzeniu legendy rzekomego spalenia diariusza wspomina Ewa Popielarz w studium Jakub Sobieskijako diarysta - na materiale „Diariusza ekspedycyjej moskiewskiej dwuletniej królewicza Władystawa” (1617-1618), w: Z dziejów staropolskiego pamiętnikarstwa. Przekroje i zbliżenia, red. P. Borek, Kraków 2012, s. 165 . 
rząc pamiętnik okresu dymitriad aż po próg 1619 r. Sądzić należy, iż memuar obejmujący lata 1584-1618 powstawał w domowym zaciszu już po powrocie z wyprawy moskiewskiej. Zwrócono już uwagę na przekomponowanie partii finałowej tekstu na podstawie zapisków w diariuszu. Twórca obudował pierwowzór przesłaniem dydaktycznym oraz wpisał weń argumentację religijną, sankcjonującą konieczność polskiej interwencji w państwie moskiewskim. Pośrednim dowodem na taką właśnie chronologię powstawania diariusza i pamiętnika okazuje się analogiczna poniekąd sytuacja w spisywaniu (niezbyt przecież odległych czasowo) relacji chocimskich. Sobieski najpierw stworzył diariusz, a następnie na jego podstawie opracował znakomity pamiętnik, który doczekał się druku. O ile diariuszowy opis kampanii chocimskiej charakteryzował się wiernością i detalicznością odtworzenia rzeczywistości, o tyle memuar - nie tracąc cech relacji werystycznej - zawierał pewne skróty, uogólnienia, większy ładunek perswazyjny. Ponadto minione wydarzenia podlegały estetyzacji (styl podniosły, wprowadzenie do narracji wielu dokumentów) i waloryzacji. Selekcja materiału miała służyć z góry założonym celom wychowania rycerskiego rzeszy herbowych, dla których zwycięstwo chocimskie (bo tak interpretowano podówczas powstrzymanie nawały tureckiej) było budującym egzemplum ${ }^{25}$. W przypadku relacji moskiewskich pamiętnik, jak zaznaczono, charakteryzuje się większym uporządkowaniem faktów, ich selekcją, a ponadto uogólnieniem wskazującym na porażkę polskiej polityki dynastycznej. Sobieski zdaje się mieć krytyczny stosunek do dymitriad oraz polskiej racji stanu w zakresie interwencji moskiewskiej. Oczywiście przez użycie zabiegów retorycznych (np. amplifikacji) stara się „udowodnić” pewne korzyści drogi moskiewskiej, lecz łatwo spostrzec, że satysfakcjonuje go rozejm dywiliński.

Wracając do Diariusza ekspedycyjej moskiezeskiej, trzeba zauważyć, iż autor spisywał go na bieżąco, niekiedy opuszczając lub rekapitulując wydarzenia z kilku dni. Mamy zatem do czynienia z klasycznym dziennikiem wojennym, gdzie osią konstrukcyjną pozostaje chronologiczne następstwo zdarzeń, a o wyborze opisywanej materii decyduje najczęściej udział piszącego w zaistniałych wypadkach. Sobieski inicjuje relację deskrypcją warszawskich uroczystości z 5 kwietnia 1617 r., mających na celu godne pożegnanie królewicza Władysława. Dnia następnego, po wysłuchaniu mszy, dwór udał się do Pragi, a 11 kwietnia doszło

25 Zob. A. Nowicka-Jeżowa, Barok polski między Europa i Sarmacja, cz. 1: Profile i zarysy całości, Warszawa 2009-2011, s. 283. 
do łzawej sceny, gdy królewicz pod Żelechowem żegnał rodzica „z płaczem okrutnie wielkim i swoim, i wszytkich”. Zwięzłe noty informujące o kolejnych postojach wskazują Lublin, Krasnystaw, Łuck i Krzemieniec. Od początku drogi towarzyszyły królewiczowi oddziały żołnierzy wraz z rotą wojewodzica lubelskiego (autor wspomina o tym pod zapisem z 6 maja). Sobieski jest bardzo oszczędny w swej relacji aż do schyłku września, kiedy do Władysława, stacjonującego pod Smoleńskiem, dołączył Chodkiewicz. Uzgodniono, że wojsko hetmańskie połączy się z oddziałami Zygmuntowicza pod Dorohobużem 9 października. Miasto poddało się dwa dni później, składając przysięgę wierności carowi Władysławowi:

U bramy zaszli mu [Chodkiewiczowi - P.B.] wojewodowie i strzelcy, Kozacy i bojarowie, czołem bili, choraggwie pod nogi podali, o miłosierdzie prosili. Popi wyszli z krzyżami, z obrazami i posadzcy ludzie, to jest pospólstwo, z chlebem i z solą. [...] Królewicz wyszedł przed namiot, siedział na stołku, kupa około niego towarzystwa stała. Wojewodowie, na twarz upadszy, o miłosierdzie prosili; chorągwie, których było dziesięć, a jedenasty proporzec, pod nogi podrzucili, popi dali mu potym krzyże z obrazy całować. $\mathrm{P}$ [an] kanclerz litewski miłosierdzie im carskie od królewicza obiecał ${ }^{26}$.

Poddanie się Dorohobuża i przejście na stronę Zygmuntowicza jednego z moskiewskich dowódców (Iwana Adadurowa) wpłynęło niewątpliwie na kolejny sukces, jakim było poddanie się Wiaźmy (19 października). Sobieski wspomina pod datą 29 października o przyjeździe następcy tronu do miasta, gdzie „popi wszyscy z strzelcami, z bojarami, z posadzkiemi ludźmi, z solą i chlebem wyszli, witając królewicza jako cara swego" ${ }^{27}$. W Wiaźmie postanowiono przeczekać zimę, by następnie kontynuować marsz w stronę Moskwy. Sobieski rekapituluje zdarzenia listopadowe i grudniowe, pisząc o licznych utarczkach polsko-moskiewskich w okolicach Białej, Kaługi ${ }^{28}$, a także Możajska, który wcale nie zamierzał się poddać. Diarysta stara się być obiektywny w rekonstruowaniu wypadków, nie kryje informacji o niepowodzeniach. U schyłku listopada doszło na przykład pod Możajskiem do pogromu rozlokowanej po wsiach dworskiej czeladzi (,,siła ich nałapali i z końmi, między innemi królewicza chorążemu dwanaście pacholików"), a 6 grudnia rozbito w tych okolicach dwie

${ }^{26}$ J. Sobieski, Diariusz ekspedycyjej..., s. 25.

27 Ibidem, s. 28.

${ }_{28}$ Tu działała z powodzeniem dywizja lisowczyków - por. H. Wisner, Lisowczycy, Warszawa 1976, s. 73-74. 
kozackie roty, posłane pod miasto „dla języka”. Wobec ustatycznienia działań wojennych na skutek zimy Sobieski skupia w diariuszu uwagę na konsyliach, strategicznych decyzjach Władysława $\mathrm{i}$ hetmana, wymianie korespondencji z bojarami. Moskiewskie listy, które streszcza diarysta, poświadczają, iż w tym czasie przeciwnicy „o królewiczu ani wspominać chcą”. Morale wojskowe psuły u schyłku grudnia roszczenia dotyczące zaległego żołdu. Traktujący z żołnierzami komisarze (29-30 grudnia) dali asekurację wypłaty pieniędzy oraz zaciągnęli wojsko na kolejną ćwierć (do 13 marca). Po kilku miesiącach zmagań do obozu królewicza dotarło poselstwo z Moskwy (3 kwietnia) z propozycją podjęcia traktatów. Po kilku jałowych spotkaniach odprawiono posłów (18 kwietnia), co podsumował Sobieski słowami: „i tak rebus infectis ojechali”. Diarysta rysuje przed czytelnikiem również kulisy polityki dworskiej, popierającej marsz w stronę Moskwy. Otóż pod 10 kwietnia autor zanotował, iż przyszły nowiny z Warszawy o ustaleniach sejmowych. Wedle oficjalnej wersji uchwalono dwa pobory na finansowanie kampanii, wedle danej komisarzom in secreto - niczego nie uchwalono, przesuwając decyzję na kolejny sejm. Warto przywołać ironiczny komentarz diarysty: „Ta nowina skoro jedno przyszła, kazano i dla żołnierzów, i dla Moskwy, a nabarziej dla posłów udawać, że sześć poborów pozwolono". Świętując sukces, w dniu następnym „publice kazano śpiewać Te Deum laudamus, z trąbami i bębnami, z strzelaniem dział i piechoty z muszkietów”, „był i sam w kościele publice królewicz” ${ }^{29}$.

Wyjazd królewicza z Wiaźmy nastąpił stosunkowo późno, bo dopiero w połowie czerwca 1618 r. Po drodze deliberowano, czy udać się w stronę Kaługi (to stanowisko forsował Chodkiewicz), czy też Możajska (ku czemu skłaniała się większość komisarzy). Ostatecznie wybrano drugie rozwiązanie. Nastroje w polskim obozie nie były najlepsze, jak zaznacza diarysta, gdyż doszło do konfliktu pomiędzy Chodkiewiczem a Marcinem Kazanowskim, który nie kwapił się do poddania pod rozkazy hetmana $3^{\circ}$. O próbę zwaśnienia magnatów oskarżono przed królewiczem nawet Sobieskiego (,i na mię winę kładąc”), z czego ten później się wybronił. Dalsze etapy drogi obejmowały krótkie oblężenie Borysowa (7-8 lipca) i podejście pod Możajsk (9 lipca).

W całej relacji diariuszowej znajdziemy kilka opisów zmagań, w których Sobieski uczestniczył. Żywością narracji wyróżniają się zwięzłe rekapitulacje walk pod Możajskiem z 15 lipca, 4 sierpnia, 11 i 22 października. Pozostałe dni diarysta wypeł-

29 J. Sobieski, Diariusz ekspedycyjej..., s. 49.

$3^{\circ}$ Konflikt ten detalicznie opisuje Jerzy Ossoliński - zob. J. Ossoliński, Pamiętnik, s. 73-79. 
nia narracją o marszach, odbywaniu narad w polsko-litewskim obozie i paktowaniu z posłami moskiewskimi. Wizyty poselstw autor często streszcza jednym zdaniem, stwierdzając, że niczego konkretnego nie przynosiły ${ }^{3}$. W czasie pobytu pod Możajskiem $\mathrm{z}$ początkiem września doszło do ujawnienia niepokoju $\mathrm{w}$ pułku Kazanowskiego, który domagał się uregulowania płatności, „z płaczem nędzę i głód swój opowiedając” ${ }^{2}$. Komisarze obiecali wypłatę części pieniędzy 28 października ${ }^{33}$, z czego wojsko nie było jednak zadowolone. Armia królewicza dotarła pod stolicę z początkiem października, tam dołączył do niej Piotr Konaszewicz-Sahajdaczny z Kozakami. W nocy z 10 na 11 października przypuszczono szturm do Moskwy. Opis zmagań w tym dniu wypada uznać za najlepszą partię Diariusza ekspedycyjej moskiewskiej. Sobieski ze znawstwem rekonstruuje kolejne fazy ataku na Bramę Arbacką (Karwacką), pod którą Bartłomiej Nowodworski podkładał minę ${ }^{34}$. Wysadzenie fragmentu umocnień nie spowodowało jednak wkroczenia do miasta, gdyż obrońcy dali skuteczny odpór ${ }^{35}$. Zwieńczenie relacji z wydarzeń tego

${ }^{3}$ I Por. H. Wisner, Król i car. Rzeczpospolita i Moskwa w XVI $i$ XVII wieku, Warszawa 1995, s. 77 i n.

32 J. Sobieski, Diariusz ekspedycyjej..., s. 71.

33 Wedle kronikarza: „Komisarze próbowali - jak tego wymagała konieczność - uspokoić rozwścieczonych żołnierzy prośbą i perswazją, obiecując rychłe nadejście pieniędzy. Żołnierz był głuchy na te prośby i pozostał niewzruszony. Tak nieustępliwym stał się z powodu niedostatku. Nadzieja udzielenia mu pomocy żywnościowej z zewnątrz nie przekonała go, ponieważ sama jej zapowiedź nie mogła nikomu przedłużyć życia. Po wielu sporach uspokoili się dopiero wtedy, kiedy została wśród nich rozdzielona suma kilku tysięcy. Wypłacenie pozostałej kwoty, obwarowane pewnymi warunkami, nastąpi, jak obiecano, 28 października”. S. Kobierzycki, Historia Wtadystawa, królewicza polskiego i szwedzkiego, wyd. J. Byliński, W. Kaczorowski, przeł. M. Krajewski, Wrocław 2005, s. 246.

34 W diariuszu czytamy: „Szedł p[an] kawaler z petardą do Arbackiej Bramy takim sposobem: wprzód dla wyrąbowania ostróżka piechota $\mathrm{p}$ [ana] kawalerowa, dla odstrzelania chorągiew Butlera i Begla cudzoziemcy, za nim Madryl do petardy ze dwudziestą knechtów, niesiono za niemi petardy ze dwudziestą, potym p[an] kawaler sam szedł ze mną i z dworem królewiczowym i towarzystwem zbrojnym p[ana] Kossakowskie[g]o i p[ana] hetmana i moim person piędziesiąt, za niemi Learmonta i Sejowa piechota szła, a za niemi Czapliński swym pułkiem lisowczyków miał posiłkować. Do drugiej też była bramy zordynowana petarda, do Twerskiej. [...] U naszej Arbackiej Bramy p[an] kawaler wysadził wrota u ostróżka petardą, był już w bramie, ale postrzelony w tęż rękę, co i pod Możajskiem (bo naszy wręcz się z nimi siekli w bramie), a do tego, że nasza kupa gęstą strzelbą zrażona ustępować musiała, nie widząc posiłku, bo i lisowczykowie nie posiłkowali, i piesze roty niespełna byli, ustąpić musiała tedy do samej bramy, nie petardując, z taką szkodą, że trzydzieści naszych trupów wzięli, między któremi Jankowski, p[an]a Kossakowskiego towarzysz, na placu podle mnie zabity ostał, Modrzejowski, mój sługa, potym w obozie umarł”. J. Sobieski, Diariusz ekspedycyjej..., s. 76-78.

35 Potwierdza to Sobieski również w pamiętniku: „Do bramy Karwackiej JM pan kawaler Nowodworski szedł z petardą i wysadził sztukę fortu (u pierwszych 
dnia stanowi zwięzły opis Moskwy, której Sobieski przyglądał się z zewnątrz.

Tu trudno przestąić situmi pozór stolicy, co oboje inter pulcherrima orbis terrarum liczyć się może. Leży w haniebnie srodze wielkiej równinie, lasów ani puszcz blisko koło siebie nigdzie nie ma, tylko niski jałowiec. Około niej zewsząd, jako gwiazdy jakie, manastery i cerkwie murowane świcą się, pod nię trzy rzeki przednie idą: Moskwa, Jauza, Nieglinna, oprócz derewiennego horodu, jako zwali, to jest nie murem, ale parkanem opasanego, który był barzo wielki i przeszłych wojen spalony, ma w sobie troje mury i trzy wielkie miasta: białe mury, miąższe barzo, które pewnie na milę dobrą ambitum mają w sobie; drugi mur czerwony tak zowią dla cegły, a w nim miasto Kitajgród; trzeci mur, w którym Krymgród jest miasto, kędy carowie mieszkają sami. Wszytkie te miasta jako osobne mury mają, tak i wieże, i bramy, pełno w nich manasterów i cerkiew murowanych, niektóre są cerkwie z pozłocistemi wierzchami. Owo rozumiem, że trudno na świecie widzieć miasta takiego, które by pozorniejsze ab extra i piękniejsze przy takiej wielkości być miało. Wewnątrz drewniane są domy i dwory, oprócz w carskim pałacu samym jest muru sztuka ${ }^{36}$.

Wrażliwy na uroki miasta Sobieski musiał rzeczywiście być oczarowany widokiem dźwigającej się po niedawnych pożarach Moskwy. Umieszczenie stolicy w szeregu najpiękniejszych metropolii Europy na pewno nie było przejawem hiperbolizacji, lecz autentycznym podziwem - tym bardziej że przecież diarysta odbył liczne podróże po krajach europejskich ${ }^{37}$.

Jakub Sobieski, rekapitulując dalsze wypadki, zwraca uwage na podjęcie negocjacji pokojowych z delegacją carską. Decyzji o zaprzestaniu dalszych walk sprzyjało przywiezienie do obozu 4 listopada listu królewskiego i „pisma Rzeczypospolitej”, w których proszono królewicza, by ten „uchylił prawa swego z woli Bożej dla Ojczyzny”. Co prawda Władysław ruszył jeszcze obóz na północny wschód od Moskwy (Monastyr Troicki), ale była to raczej demonstracja siły niż manewr służący zdoby-

wrót, gdzie go w rękę postrzelono), ale że dziura była niewielka i że był mocny sztakiet wewnątrz, i wrota drugie warowne, trudno było radzić. Do drugiej bramy Twerskiej panu staroście zatorskiemu nie zdarzyło się przysadzić petardy i dwu całych petard odbieżeć musieli" (s. 148). Jerzy Ossoliński zanotował w pamiętniku, iż wespół z wojewodzicem lubelskim dali tego dnia dowody szczególnej odwagi (J. Ossoliński, Pamiętnik, s. 81-83).

$3^{6}$ J. Sobieski, Diariusz ekspedycyjej..., s. 78-79.

37 Por. A. Sajkowski, W stronę Wiednia. Dole iniedole wojenne wświetle listów i pamiętników, Poznań 1984, s. 90. 
ciu Moskwy. Spotkania komisarzy z delegatami moskiewskimi trwały kilka tygodni. W obozie królewicza wzmagały się bunty i pretensje o niewypłacanie pieniędzy (2 listopada dotarła tylko część wynagrodzenia). Wedle Sobieskiego „po długich hałasach i alterkacyjach" ustalono, że zaległy żołd otrzymają „na śródpoście”, czyli przed końcem lutego.

Diarysta wprowadził do relacji osiemnaście punktów rozejmu, który zawarto w Dywilinie. Po złożeniu przysięgi i podpisaniu warunków traktatowych wymieniono grzeczności: „Potym częstowaliśmy ich konfektami i siedzieliśmy z sobą więcej niż pół godziny, rozmawiając już z sobą po przyjacielsku et inter seryją żarty mieszając. Potym pożegnawszy się z sobą, rozjechaliśmy się" ${ }^{8}$.

Jak zauważono, pełniący funkcję komisarza Rzeczypospolitej Sobieski nie był zwolennikiem kampanii moskiewskiej w zwieńczeniu pamiętnika wprost mówi o „tragedyi moskiewskiej" ${ }^{39}$. Relacja diariuszowa stanowi werystyczny zapis kolejnych etapów wyprawy z lat 1617-1618. Autor, niczym Tacyt i Tukidydes, na których lekturze zresztą się wychował ${ }^{4 \circ}$, dokumentuje męstwo swoich rodaków, $\mathrm{z}$ rzadka tylko napomykając o sobie. Znamienne zresztą, że stosuje przemienne techniki narracji wspomnieniowej, posługując się narracją pierwszoosobową oraz - zgodnie z tradycją pamiętników cezariańskich - trzecioosobową. Diariusz i pamiętnik, wedle autorskiego zamysłu, miały pełnić zarówno funkcję dokumentującą, jak i upamiętniającą.

\section{PIOTR BOREK}

\section{Jakub Sobieski's Description of the Moscow Campaign (based on the Diariusz ekspedycyjej moskiewskiej dwuletniej królewica Wtadystawa Anno Domini 1617 [The Diary of the Two-Year Moscow Campaign by Royal Prince Władysław in 1617])}

The essay discusses Jakub Sobieski's diaries and memories, which belong to the finest specimens of such writing in Polish Baroque. The diary and memoirs of the Moscow campaign of 1617-1618 have survived in only a few copies, with the most important ones in Biblioteka Czartoryskich in Cracow. Reconstruction of Prince Władysław's strug-

$3^{8}$ J. Sobieski, Diariusz ekspedycyjej..., s. 94.

39 XVII-wieczny biograf Władysława IV, S. Kobierzycki, wystawił Sobieskiemu znakomite świadectwo, pisząc o jego wielkiej roztropności dyplomatycznej w zakresie podpisania traktatu - zob. S. Kobierzycki, op.cit., s. 272.

$4^{\circ}$ Por. Z. Trawicka, Jakub Sobieski..., s. 29. 
gle for the Russian crown is mostly based on a handwritten testimony called Diariusz ekspedycyjej moskiewskiej dwuletniej królewica Wtadystawa A. D. 1617 [The Diary of the Two-Year Moscow Campaign by Royal Prince Władysław in 1617]. The events described in the diary span from April 5th, 1617 to December 28th, 1618. The author has arranged the material chronologically, focusing on the text as historical evidence. The conclusion of the text, where Sobieski quotes a fragment of Tacitus's Annals, points out to the argumentative function of the work, which was supposed to explain to Poles (the king, the sejm and senate, the nobility) that commissaries were right in signing the Truce of Deulino, regarding the safety of the homeland threatened by Turks and Tatars, and the budgetary difficulties of the Crown and Lithuania. The second work by Sobieski is more of a Baroque memoir, composed as a temporal sequence (some fragments have the structure of diary). The author reconstructs the events of the Moscow campaign, beginning with the death of tsar Ivan the Terrible (1584), and leads the narrative to the end of 1618, when the Truce of Deulino. The work is characterized by greater coherence in presentation of facts, their selection, and a more general point of view, pointing out to the failure of Polish dynastic policy. Sobieski seems to be critical of the Polish intervention and the Polish raison d'état in this respect. He is also critical of the young prince's campaign of 1617-1618; he was a commissioner for treaties with Moscow during the campaign.

Keywords: Jakub Sobieski, memoir, diary, war, Polish intervention in Russia during the Time of Troubles.

Piotr Borek - profesor zwyczajny w Katedrze Literatury Staropolskiej i Oświeceniowej Instytutu Filologii Polskiej UP w Krakowie, od 2009 r. jego dyrektor. Członek Komitetu Nauk o Literaturze PAN, Komisji Historycznoliterackiej PAN, Komisji Wschodnioeuropejskiej PAU. Członek redakcji „Studia Romologica”. Zainteresowania i problematyka badań: staropolskie pamiętnikarstwo, barokowe piśmiennictwo użytkowe i literatura okolicznościowa, barokowa epika, testamentologia, edytorstwo tekstów dawnych; dzieje i kultura Romów, historia i kultura dawnej Ukrainy. Autor i wspóltwórca wielu prac $\mathrm{z}$ tego zakresu (w tym także edycji źródłowych tekstów staropolskich wydawanych w serii Biblioteka Tradycji i innych: J.T. Józefowicza, J. Białobockiego, S. Leszczyńskiego, S. Makowieckiego, S.H. Szymanowskiego, D. Bratkowskiego), między innymi współredaktor publikowanych niedawno tomów zbiorowych: Literatura - Kultura - Edukacja (2012), Z dziejów staropolskiego pamiętnikarstwa. Przekroje i zbliżenia (2012) oraz autor książki $W$ stużbie Klig. Studia o barokowych pisarzach „minorum gentium” (2011). 